\title{
"Trying to Walk on Logs in Water": John Donne, Religion, and the Critical Tradition
}

\section{JEANNE \\ SHAMI}

Résumé : Cet article examine la religion de John Donne du point de vue historique ainsi que littéraire, en mettant en valeur ses rapports avec les branches catholique et réformée de l'église anglicane en début de l'époque des Stuart. Ses écrits révèlent les fêlures de cette église et illuminent les versions plus extrêmes et moins sophistiquées des conflits qu'il incarnait lui-même. En particulier, la poétique sacramentelle de Donne, sa rénovation de termes réfutés et ses formulations rhétoriques paradoxales témoignent des accommodations avec le Catholicisme qui marquent sa via media comme variable et instable et qui servent de preuve exemplaire des efforts de l'église anglaise de rester unie.

Tnterest in Donne's religion is increasing. Evidence of this claim is everywhere in the current critical discourse, but I want to begin my analysis by describing a remarkable occasion, a panel discussion at the annual meeting of the John Donne Society, held on 22 February 2002. ${ }^{1}$ Normally, that place in the program is reserved for discussion of pedagogical issues raised by one of Donne's "teaching texts," and, normally, the panel discusses one of the more popular Songs and Sonets. As incoming President of the Society in 2002, with a well-known penchant for Donne's sermons, I had tempered my original plan - to assign an entire sermon - in favour of the more moderate one of choosing "A Litanie." At first glance, this selection did not seem promising to all: the poem was too long, too verbally and conceptually complex, too religious for most "lay" readers of Donne, and even the "clergy" - those specialists attuned to the poem's intellectual and aesthetic demands - were not convinced of the value of the experiment. On the day of the session, the first order of business - reading the poem aloud as a prelude to the panel — was deferred until after the discussion, at which point 
members of the audience were invited to read a single stanza, as they did almost spontaneously, and to our surprise, very movingly. ${ }^{2}$ As Dayton Haskin describes the moment, this engagement with "A Litanie," while rare in Donne studies, brought into focus much that we find most difficult in Donne, even as it highlighted the poverty of readings that "would make Donne's poems yield up evidence of his apostasy, or of his having written under the spell of a biblical poetics unique to Protestants, or out of desperate ambition to secure a place." 3 "A Litanie," in fact, enacts the uneasy relationship between Donne's conformity and his conscience, illuminating both the historical "conversion" of the Church of England at the Reformation and the personal consequences of that conversion for Donne's faith, his poetics, and his life.

Annabel Patterson's commentary on the poem that day made even more provocative claims for its importance. "It contains more information about his theology in the years after his conversion but before his decision to take orders than any other document," she said, but suffers by popular preference for the love poems, by its inordinate length, and by contemporary taste which finds it too liturgical, too cerebral, and completely devoid of sex. ${ }^{4}$ Of course, another reason for its neglect might be added to these: historians have not adequately constructed the political, social, ecclesiological, or religious terms in which such a poem might be interpreted. Nor is the basic shape of Donne's biography, which might serve as a framing context, undisputed. In fact, the challenges of Donne's biography - the historiography of the individual life - are a microcosm of certain historiographical debates about the residual Catholicism of the Church of England. As Haskin demonstrates, "with few exceptions, every attempt to extract biographical information has been entangled in assumptions about a larger, more complex life-narrative organized around the trope of conversion," but based on no consensus "about when the decisive change in Donne's life really happened or what precisely it entailed." 5 Patterson aligns these perspectives when she says that "Meane waies' could be a subtitle for 'A Litanie,' another, more advanced version of the via media, which not only mediates between far right and far left on the confessional spectrum [what one might call the 'historical' context], but extends the idea of the mean into most aspects of ethical and religious conduct [thus linking the former to the 'biographical']." Her essay concludes that understanding this poem can illuminate Donne's "endlessly shifting middle position." "In this intermediate period between Satire 3 and taking orders," she says, "Donne did not see the idea of the middle as the search for a quiet space of clarity between excesses and extremes. It was more like trying to walk on logs in water."7 


\section{Donne's Religion and the Via Media}

Scholarly engagement with John Donne is captured in the language of Patterson's discussion of "A Litanie." So, too, is the history of scholarly commentary on the question of Donne's religion. At least since the nineteenth century, and, arguably, long before, Donne was understood as a via media Anglican. The log-rolling metaphor, however, expresses our current sense of Donne's shifting and unstable via media - the very religious position enacted so compellingly in the metrical and tropic complexities of "A Litanie" in 1609 and in Donne's sermons until 1631. ${ }^{8}$ It also expresses our current perspective on Donne's relations with both the Catholic and Reformed strands of the English national church in the Jacobean and early Caroline years, even as it moves away from earlier articulations of Donne's institutional and personal allegiances — and the relations between them. In some ways, we continue to reiterate this earlier view, except that the middle way most scholars posit now is richly nuanced, and connected compellingly to biographical and historical narratives that challenge some of the most deeply held assumptions about Donne and his religion: his conversion (understood as apostasy "from" Catholicism but "to" nothing readily definable), his grasping ambition, his coterie, his absolutist politics, and his function as spokesperson for the evolving English church dominated by Laud. As our fascination with the paradoxical rhetorical positions he adopts indicates, we are still seeking to understand the imaginative relationships between Donne's "Poetiqueness" and the "Meane waies" in religion that were his abiding concern.

As Haskin has demonstrated, the history of scholarship on Donne's poetic and religious identities is also the history of biographical criticism. ${ }^{9}$ Walton's Life of Donne and its popularity in the nineteenth century inscribed forever the "conversion" model for understanding Donne, a hagiographical account that has had profound impact on Donne studies. It is the metanarrative of Bald's ostensibly more objective biography, and it underwrites Carey's narrative of "apostasy" and "grasping ambition." 10 Even those who acknowledge the temporal change, however, have had trouble accepting the sincerity of the religious conversion, and consequently have spoken of religious works, primarily the sermons (supposedly written after the conversion), as the products of expediency or of a self-serving rhetorical virtuosity. This latter view lies behind T. S. Eliot's assessment of Donne and informs his comparison of Donne with Andrewes. Eliot's Donne is a "personality" who uses his sermons as a means of "self-expression." 11 He is someone in love with his own voice, seeking "refuge in religion from the tumults of a 
strong emotional temperament which can find no complete satisfaction elsewhere."

One consequence of Eliot's work was to fix Donne as an icon of high-church Anglicanism, the exemplar of its via media between Rome and Geneva, and a spokesperson for its absolutist monarchs. ${ }^{12}$ Increasing interest in Donne's prose in the twentieth century, in large part driven by Evelyn Simpson and George Potter, and culminating in their edition of the Sermons between 1953 and 1962, established this orthodoxy of Donne's middle way even more firmly. ${ }^{13}$ In the early 1960 s, William Mueller consolidated and advanced this view in his John Donne Preacher. "John Donne," he says, "was an early seventeenth-century Anglican to the core. If the Divine Comedy is a literary monument to Thomism and The Pilgrim's Progress the dramatic embodiment of Puritanism, then the Sermons of Donne are the most compelling presentation of that Summa of Anglicanism: Richard Hooker's Of The Laws of Ecclesiastical Polity." 14 The Donne he presents was one who not only followed but "indeed helped to form" the "Anglican position, the middle way between the Roman and the Reformed theologians. He shared with Luther and Calvin and their followers the fear that much of the apparatus of Roman belief and practice detracted from the glory of God.... But like many good things, the Reformed movement had, Donne felt, gone too far. . . . If Rome had seemed to overassess man's role, Geneva had seemed to reduce it by a ruthless logic to zero." 15 Mueller goes on to say that while "Donne's position might not stand the full test of logical argument," he was committed to the paradoxical view that "on the one hand, man is absolutely governed in his every action by God and, on the other, that man is nonetheless a responsible moral agent, called upon to choose between life and death and empowered to do so through God's grace." 16 Mueller is alluding to Donne's place in the Church of England's disputes over the theology of grace. Increasingly virulent and politicized controversial debate over that doctrine, the foundation of the Reformation, now exposed fault lines in its religious settlement and threatened to fracture the institution. Mueller's Donne is an engaging, spiritually grounded, sincere, and charitable preacher, firmly in the middle way of the Anglican Church, and skilled above all in "making the Biblical text so relevant to the everyday lives of men." 17

Mueller's groundbreaking work on Donne's sermons still has some explanatory power regarding the question of Donne's religion because his stress on paradox implicitly challenges the either/or paradigm, the necessity to see change and continuity as mutually exclusive. However, the revisionist movement in early Stuart religious historiography not only made reassessment of Donne possible, but necessary. In fact, it might be said that the 
particular trajectory of Donne scholarship has paralleled the broader developments of modern revisionist and post-revisionist historiography. The first thing to go was the use of binary terms - Anglican and Puritan - to describe the confessional divide in the early Stuart church. In fact, the term "Anglican" was declared anachronistic for this period, and for a time the term "puritanism" threatened to disappear, especially as a force for cultural change. ${ }^{18}$ In the view of Tyacke and his disciples, the dominant doctrinal orthodoxy of the Jacobean church in which Donne preached was Calvinism, and the destabilizing force that ultimately led to civil war was not Puritanism but Arminianism. ${ }^{19}$ Scholars of early-modern religious history now spoke of a spectrum of Protestant orthodoxy that ranged from "crypto-popish 'Arminian' zealots on the one hand, through to die-hard puritan non-conformists on the other." ${ }^{20}$ On the margins of the spectrum were Protestant separatists, and at the other extreme, Roman Catholic recusants. The former were those who could not conform, even outwardly, to the disciplinary requirements of the English Church, and whose disciplinary objections modulated increasingly over time (and under polemical pressure) into doctrinal differences. The latter were Catholics who retained their commitment to the Church of Rome, and who refused to communicate within the Church of England. In the middle were a variety of religious orientations, ranging from reluctantly conforming Puritans (those whose differences with the Church of England were largely disciplinary rather than doctrinal), on the one hand, to "church-papists," on the other (those who conformed willingly to the discipline but retained deep doctrinal reservations about the Reformed religion), with a broad centre of conformists, most of whom were Calvinists. ${ }^{21}$ But also within that centre, and challenging its doctrinal dominance, were conformists variously labelled in Donne's time as Arminian or Pelagian (by the names of ancient heretics or their later counterparts), and today as avant-garde conformists, anti-Calvinists, and Laudians, classifications which overlap doctrinal and ecclesiological boundaries, and which describe groups that are neither coherent in themselves nor reducible to a common term. With its focus on sermons, the scholarship of Peter Lake forged a vital link between literary and historical modes of analysis to describe "the endless permutations of opinion and position that characterized this fragmented yet inclusive Church." 22 More than any other historian, Lake has presented a "Church of England marked by social, cultural, ecclesiological, and theological complexity," by moving beyond the simplistic "uninflected close readings" of revisionist histories, and by recognizing that to adopt uncritically the labels of seventeenth-century controversial polemic unwittingly made historical narrative the mouthpiece of the self-representations of the past. ${ }^{23}$ 
Recent scholarly assessments of Donne's religion and politics mirror this broader historical debate on religious labelling, in part because they allow for a more complex and shifting religious identity than that proposed by the older Anglican/Puritan configuration, in part because they are more historically detailed. Within that spectrum, Donne has occupied virtually every known position: Donne of the Puritan imagination; Donne the "Calvinist Episcopalian"; Donne the conformist; Donne the avant-garde conformist, Donne the Arminian. These Donnes range from reluctant to enthusiastic conformity to the Church of England, from an emphasis on godly preaching to a preference for sacrament and ritual, from connection with international Protestantism to connection with Rome, from predestinarian theology to a stress on universal grace and good works. And this labeling of Donne has been supported by re-deployment - and in some cases discovery - of biographical information. ${ }^{24}$

Although the "spectrum" of confessional positions possible even with the orthodoxy of the early Stuart Church has achieved normative status, scholars have begun to turn their attention to the residual Catholicism of the English church in a move that will continue to lead to important connections between historians and Donne scholars. Due largely to the pioneering work of John Bossy and to the labors of Alexandra Walsham, Michael Questier, and Peter Lake, Catholicism is now being considered as an explanatory category without which an understanding of the English church or of many of its adherents (like Donne) cannot be achieved. Of course there has long been an understanding that the Church of England was officially anti-Catholic. ${ }^{25}$ But our idea of what it means to be either Catholic or anti-Catholic has been immeasurably complicated and enriched by the work of the scholars mentioned above. ${ }^{26}$ In their most recent scholarship, Lake and Questier have further uncovered the complexities of the history of early modern English Catholicism by demonstrating that, as with accounts of Reformed aspects of the Church of England, Catholicism has been characterized in dualistic terms: "roughly speaking, an 'extreme' or radical impulse or tendency, on the one hand, counterbalanced by a 'moderate' tendency or impulse, on the other," e.g., Jesuits versus secular clergy, those who would take the Oath of Allegiance versus those who refused, recusants versus church-papists. Here, too, we are told, it is unwise to impose "a misleading clarity or simplicity upon what was a complicated palimpsest of (personal, affective and ideological) allegiances, attractions and repulsions." 27 And we hear, in characteristically provocative language, that the "last unchallenged and most perniciously pervasive element in the Whig view of modern English history is an unacknowledged tendency to privilege all things protestant while sedulously marginalising all things catholic." ${ }^{28}$ Alison Shell has carried this 
notion of writing Catholicism back into history in her study of English literary culture, in the process focusing on "the importance of the category of convert, as illustrating the fluidity and dynamism of denominational membership." 29 Building on Questier's work, she notes, "Not all conversions were instantaneous, unrepeatable, road-to-Damascus experiences. The serial convert who might alternate between Catholicism and Protestantism twice, three times and more during a lifetime, and the near-convert who might hesitate between denominations for decades, both need to be allowed for in any estimate of Catholic or pro-Catholic sympathy at this time." 30

This particular historical direction is especially promising for Donne scholars. Many have found Carey's narrative of apostasy and ambition unsatisfying as an explanation of Donne's poetry, his sermons, or his religion. But Donne, the Protestant convert and saint of Walton's biography-and of Lewalski's Protestant poetics-is equally inadequate. Too much of Donne's work defies these categories and definitions, and some exciting new work is addressing the precise nature of Donne's religion-and, specifically, of his Catholicism - as an explanatory category.

Not surprisingly, the foundational emphasis for such a study has been biographical. As early as 1920, Louise Guiney urged that "Some one, first in that field, should write a little book, which should be a scientific and authentic study of Dr. John Donne as a Catholic." 31 Her suggestion is the life work of Dennis Flynn and has informed the scholarship of many readers. Several important and related topics have emerged: conformity (and its relationship to confessional identity), ${ }^{32}$ Donne's interpretive habits and the flexibility of his middle way, ${ }^{33}$ Donne's sacramental poetics. ${ }^{34}$ The rediscovery of sacramentalism at the turn of the twenty-first century, the focus of Joan Webber's Contrary Music in $1963,{ }^{35}$ now takes on material form by connecting Donne's rhetoric and literary productions to liturgy and ceremony, to his communal devotional poetics, and, finally, to his Catholicism. The question of how Donne can accommodate the tensions that exist in scholarly assessments of him depends to a considerable degree on how scholars interpret the significance of the religion of his baptism in relation to his mature confessional identity, as well as to his professional commitment to constructing a uniquely English reformed church. This is not to go back to Anglicanism. But as Anthony Milton and others have shown, the nature of Catholic and anti-Catholic rhetoric in the English church is crucial to our understanding of its identity. And, though no historians (in the purely disciplinary sense) have treated Donne seriously as an important figure in the construction of the English church, their insights about the tensions fracturing and shaping the English church are nowhere better examined than in this man - a compendium of conflicts, controversies, and harmonies, 
who epitomizes the efforts of the Church to remain whole, and whose daring experiments in interpretation and rhetoric predicted its highest achievements. His writings expose the fault lines and tensions in the early Stuart church, and his resistance to labelling makes all too clear the more extreme, less sophisticated, versions of the conflicts he embodied. Such conflicts also produced some of the most compelling poetry of the age, and the intersections between religion and Donne's poetics is an important area of inquiry.

Recent scholarship on Donne's sacramental poetics has begun to probe these intersections, yielding rich results. In her study of Donne's poetry, DiPasquale takes one aspect of Catholicism, sacramental theology and conflicting conceptions of the Eucharist, and attempts to reconstruct Donne's "more nuanced theology as a guide to his poetics and, in particular, to his conception of the exchange between author and reader." 36 The result is a Donne whose statements on the Lord's Supper even in his sermons, where we would expect them to be clearer than in his poems, "fit no ready-made denominational category" but whose theology of sacramental reception nonetheless shapes readers' responses to his "poetic sacraments." 37 "Body, letter, sermon, poem, sacrament", she concludes, "all are means by which the self may convey itself to another self who is "in charyty to receave." 38 Robert V. Young's study of seventeenth-century devotional poetry takes Donne's Catholicism one step further by engaging fully with the Catholic character of his theology of grace, or at least its distance from Reformed formulations, particularly those of Calvin. He argues that Donne's particular contribution to the Church of England's via media "was the result of a residual Catholic conscience in a man who, whatever his reasons, felt compelled to conform to and, eventually, minister in England's established Protestant church." 39 Like Lake, Questier, and Shell, Young challenges the claims for the absolute dominance - official or otherwise - of Calvinism in the Jacobean English church, arguing instead for a religious imagination that was richly imbued with Donne's individual and the English church's communal Catholic heritage. His reading of Donne's conception of "real presence" in his sermons exposes a deeply ambivalent but remarkably "Catholic" - even Tridentine - formulation that represents "Donne's unsettled conscience" even as minister of the Church of England. ${ }^{40}$

Robert Whalen's recent study records Donne's "startling record of the relevance of the sacrament for the profane aspects of poetic experience." 41 Like DiPasquale and Young, he is uncertain how to interpret Donne's intentions, although, also like them, he describes the rhetorical complexity of Donne's formulations admirably. Whalen argues that Donne's sacramental topoi evince his desire to transcend his subjective anxieties, but, despite offering an engaging discussion of the doctrine of real presence in one of 
Donne's sermons, he concludes that Donne is here playing with rather than constructing sacramental ideas. Whalen also finds these doctrinal conflicts in Catholics before the Reformation and in the Reformers themselves, identifying Donne finally with the sacramental puritanism (as he calls it) of one who feels the conflict between his utter helplessness as a sinner and his determination to make himself acceptable. The discussion of Donne's 1626 Christmas sermon finds Donne conferring sacramental status on the word preached and heard (as a means of grace), a soteriological effect analogous to the breaking of Christ's body in the Eucharist, and one that enlarges considerably the sacramental possibilities for Christians in the Church of England.

Witty applications of Donne's sacramental theology to his poetics aside, all three of these commentators wrestle with Donne's equivocal language - and intentions - in his formulations of that theology in the sermons. Tacitly, their discussions assume that, of all the genres in which Donne wrote, the sermons - whose function is didactic and edifying ought to provide the greatest clarity on this issue. However, DiPasquale finds Donne evoking "many different Catholic and Protestant formulations," intermingling figurative and bodily understandings of Christ's presence in the Eucharist, and the ways in which sacraments convey grace. She cites the sermon of 6 May 1627 to show how Donne "defines the English Church's notion of Eucharistic sacrifice very carefully [she later says 'equivocally'] in terms that evoke the Tridentine notion of 'applying' Christ's sacrifice even as they reject Bellarmine's insistence that sacrifice necessarily involves the destruction of that which is sacrificed." 42 Young finds Donne's views regarding the real presence equally enigmatic, noting that he condemns the carnality of the Catholic doctrine of transubstantiation, while he nonetheless "conveys a vivid sense of Christ's presence in the physical elements of the sacrament." Young explains the "problematic" nature of these "elusive" comments, taken collectively, as evidence of Donne's "perplexity about how much of the Catholic heritage could be retained" and of his characteristic habits of "evasion." 43 Whalen, too, notes that in these passages from the sermons, "the relative literal or figurative extent of the eating metaphor is far from clear," but concludes that "[b]y drawing an analogy between sermon and Eucharist, both of which are received and applied by his auditory," Donne "sacramentalizes the word" in a strategy that produces an "idiosyncratic contribution to the elusive English via media." 44

These scholars have passed their insights through the filtering lens of Donne's Catholicism. Looking not only at Donne's Catholicism as an idea or a poetic lexicon, however, but also at Donne as an English convert from Catholicism, and so as a person whose political and ideological doings must 
be included in any picture of the English Church of the 1620s, will correct the Whig habit of "regarding the outcomes of politically contingent events and processes as foregone conclusions" and give us some insight into a time in which "the political vision and activities of a great many (both protestant and catholic) contemporaries long remained obsessed with what one another were doing precisely because they rightly saw the current dispensation as politically contingent." 45 That means we can look at Donne's religious discourse, however metamorphosed into devotional poems or sermons or satires or love lyrics, as not merely reflecting but constructing the terms in which he understood and articulated his beliefs and desires.

Certain features of Donne's relations to Catholicism merit further study. In particular, the context of conversion (and the relation of personal conversion to the historical "conversion" of religion in the Reformation) might bear further fruit. Questier's study of conversion and conformity concludes that "[d]uring this time, within the apparently rigid constraints of doctrinal formulation and political loyalism, flux in religion was the norm rather than the exception in religious experience, actually expected rather than regarded with astonishment." 46 This flux is clearly demonstrated in Donne's sermons, and it is possible to match up numerous pairs of sermons - supporting and condemning Catholicism - for analysis. However, for our purposes here, I propose to examine two undated sermons on the Reformation delivered at Whitehall and a Paul's Cross sermon delivered on 6 May 1627. The Whitehall sermons reveal Donne heavily invested in explaining his apostasy as Reformation, and the Reformation as a paring, or "circumcision," of the Church rather than a "concision," or rending of the fabric of religion. As with all Reformed "converts," the difficulty is in distinguishing between England's reformation of Catholic abuses and current separatist moves to break from the Church of England. The Paul's Cross sermon reveals the continuities with Catholicism, particularly its ceremonies and devotions, that mark Donne's personal religious settlement, and only less precariously that of the official articles of religion of the English Church.

The sermons reveal what the uneasy paradoxes of "A Litanie" had embodied: that Donne was a product of the Reformation. The two Whitehall sermons on Ezekiel 34:19 outline Donne's treatment of the Reformation as a "circumcision," rather than a "concision," and offer historical justification and explanation of that event. ${ }^{47}$ Taking grass and water as the food ordained for sheep, Donne deftly shows how the Roman Church - with its Latin services, its feigned legends, its intoxicating "Dews of Apparitions and Revelations" (10: 145, 202-3), its excesses of humane ornament, its ignorance, its ceremonial additions, its failure to educate the laity on the proper use of the "pious signification" $(10: 151,395)$ of ceremonies, the oppressive 
power by which it intimidated its people (through slaughter and the Inquisition), the scorn with which it did these wrongs openly, its legal loopholes and exceptions (what Donne calls "Reservation of Cases" [10: 157, 620]) - had trodden upon the food of God's sheep and fouled their water. The application of these metaphors to "the condition of our Fathers in the Italian Babylon, Rome" (10: 158, 666-67) is the substance of the first sermon on this text, an anatomy of Roman Catholic abuses justifying the Reformation that focuses on the way in which the "Court of Rome" and the "Church of Rome" banded together to oppress their people.

The second sermon of the pair, however, shows Donne's deep discomfort with the similarity between Luther's Reformers and current Separatists, a conjunction that requires Donne to make careful distinctions between the two. Donne speaks powerfully of the "Contracts" and "stipulations with God" (10: 161, 66-67) that are the inheritance of one's baptism, and of the responsibilities of conversion. If "true, and established zeale" $(10: 161,74)$ is the motive, the conversion is justified, but not for temporal respects, even if the conversion is from the Roman Church to the English Church. Donne is particularly horrified by an undervaluing in the English Church of the Sacraments, in part because "our times abound with such persons as undervalue, not only all rituall, and ceremoniall assistances of devotion, which the wisdome, and the piety of the Church hath induced, but even the Sacraments themselves, of Christs owne immediate institution" (10: 162, 103-7). Moreover, by contract with God in his Church, the "instruments of our reconciliation" $(10: 165,219)$, which he names specifically as circumcision (to show continuity with the Jews, whose synagogues God did not empty, because they worked his ordinances there, until he had established his Church), baptism, and the Eucharist. These Donne calls "the Conduit of all the merits of Christ, to his soule" (10: 165, 229-30). Nor does Donne underestimate the importance of being a flock rather than an individual sheep. Yet, the Reformation became inevitable and necessary, a consequence of the driving out of the Roman Church by its oppressive abuses, and a calling of God from out of Babylon. The separation is explained in terms of the plague: "We departed not from them then, till it was come to a hot plague, in a necessity of professing old opinions to be new articles of Faith" (10: 174, 548-50). Such a necessity does not exist in the current Church of England, Donne argues, and separatists suffer from what Calvin calls "Morositatem, a certain peevish frowardnesse, ... and an ambition to have his opinions preferred before all other men, and to condemn all that differ from him" (10: 175, 586-92).

These sermons are clearly anti-Catholic — or at least anti-post-Tridentine Catholicism. Their anger and frustration reflect Donne's deep am- 
bivalence about the religion into which he was born, but also illuminate the grounds of religion for him in a way that an unchallenged religious experience would not. How do we reconcile these anti-Catholic impulses, then, with the 1627 Paul's Cross sermon, which stresses absolutely that "[i]t is not enough for a man to beleeve aright, but he must apply himself to some Church, to some outward form of worshipping God; It is not enough for a Church, to hold no error in doctrine, but it must have outward assistances for the devotion of her children, and outward decency for the glory of her God" (7: 429, 499-503). Potter and Simpson suggest that some contemporaries would have heard in this sermon "the rankest Popery" (7: 47), first in that it defends the terms "altar" and "sacrifice" as applied to the Eucharist, and then in that it argues forcefully for images as aids to devotion. Characteristically, Donne challenges the "contentious detestation of words," his age's concession to political correctness. "We dare not name Merit, nor Penance, nor Sacrifice, nor Altar, because they have been abused," he says, and wonders how people would be "disfurnished of many words in our ordinary conversation, if we should be bound from all words, which blasphemous men have prophaned, or uncleane men have defiled with their ill use of those words" (7: 429, 515-20). ${ }^{48}$ This sermon on "the right use of these pictures" $(7: 432,627)$ ends with a condemnation of "such uncharitable condemners of all those who admit any use of them, as had rather throw down a Church, then let a Picture stand" (7: 433, 653-55).

How then do we bring these anti-Catholic and pro-Catholic perspectives together? We might say that Donne is rejecting Roman additions to articles of faith as the reason for the Reformation, and arguing that the disciplinary objections of current separatists are not of the same order of magnitude. Abuses of images, if there are any, do not constitute a plague. Or we might argue, biographically, that Donne, hungering for the devotional experiences of his youth, is making political accommodations with the anti-Calvinists to support this habit, and justifying it by diminishing the outright differences between Catholic and Protestant understandings of how sacraments convey grace, how they act as ordinances within Donne's adopted Church. Perhaps we can say that Donne's anti-Catholicism is only directed against its leaders - the Court of Rome and the "imaginary universall Father," the Pope, who have failed to educate their people with the Word preached, the powerful ordinance with which the Reformed Churches have bolstered their communion. Or must we see these two positions as mutually exclusive? A purely textual or rhetorical response to Donne might indeed lead to the sense of an irrecoverable dichotomy, an implosion of public pressures upon the private conscience. But the reality is more muddled. 
Here, Anthony Milton's essay on anti-popery is instructive. What he shows is that despite the official or philosophical anti-popery in England, the situation for real Catholics was much more complex and varied. There is good evidence, according to Milton, that haters of Catholicism in fact continued to carry on economic, social, and even personal ties with their Catholic neighbours. As he says, "If the precepts of anti-Catholicism were the 'politically correct' language of the day which could never openly be challenged without considerable danger, this did not mean that they were not effectively undermined on a daily basis by norms of intellectual inquiry, political behaviour, commercial calculation and social intercourse," 49 except, perhaps, in moments of crisis. Then there is the question of conversion. Questier has shown that what was at stake in conversion is only dimly understood by modern readers. From our vantage point we mock or criticize, but in fact, even in the case of "serial" converts, there is much that readily explains the uncertainty of religious identity in Donne's time. All of the religions were fundamentally Christian, for one thing, and ties of custom, varying from one location and one generation to another, would influence choices. Charity and accommodation of differences can also not be discounted. The explanation of political expediency or hope for a pension or a good severance package has dominated the critical scholarship on this phenomenon, but little credence has been given to either the hold of the religion in which one was nurtured or the flexibility of conscience bred by religious controversy. ${ }^{50}$ In Donne's case, there is no doubt that he remained attached to the ceremonies of devotion of his youth, as well as to the Scriptures, and particularly the Word preached. Equally, there is no doubt that he hungered deeply for the "means" of salvation, a community of faith and devotion. And, with all Christians, he shared a profound confidence in the applicability of Scriptures to human action. Moreover, his casuistical training had educated him in the paths of mediation and negotiation. Finally, it seems that looking for consistency is misguided, because it supposes uniformity. Occasions matter, and so a sermon preached at Whitehall in the last years of the Jacobean pulpit offers interpretive difficulties unlike those of a sermon preached in 1627 at Paul's Cross. And at the heart of Donne's religion was paradox, a way of seeing that cut through the logic with which more literal Reformers explained salvation by describing the process of salvation as a ring, or as a chain of cause and effect. ${ }^{51}$ At any moment, in any sermon, Donne says, he focuses on only one link in the chain, but the stamp that makes it current and validates it all is the perspective of God, not of men.

When Coleridge annotated Donne, he justified reading older writers as a release from "the narrow Idolatry of the Present Times and Fashions" and 
a pursuit that can create "the noblest kind of Imaginative Power in your Soul, that of living in past ages." 52 That is why it is so illuminating, I think, to see Donne through a middle distance, as Haskin does in examining Coleridge's annotations. When we see Donne through the eyes of his contemporaries, we risk accepting as truth contemporary rhetorical and polemical formulations that we can no longer decipher, although they, too, are part of the picture. When we see Donne through our own eyes, we risk the blindness and insuperable distortions that our great distance from England in the 1620s impose, although that difficulty does not obviate the necessity of making the attempt. ${ }^{53}$ Haskin shows us that Coleridge admired Donne primarily for his independence, the independence of the true reformer. And Donne was nothing if not a reformer, in both poetry and religion, as his contemporaries realized. ${ }^{54}$ Just as his poetry recognizes no single authority and engages in no servile imitation, but grafts the best of the old onto the new, so Donne is the slave to no interpretive authority. Paradoxically, Donne, himself so singular, distrusted most the singularity of the "phoenixes" in religion. And paradox is at the heart of his religion, paradox expressed in metaphors whose power to incarnate ideas made them more powerful than any local manifestation: the "idea" of a Church and not as it was. This, as Haskin has shown, is what Coleridge recognized in Donne's sermons and what we, perhaps, have forgotten. Haskin suggests that, like Donne, "what Coleridge meant by 'the Church' was not primarily an institution to be found in the contemporary world; nor was it an abstract, unchanging ideal. The annotations show that the interpretive community he had in mind was made up of thoughtful interpreters living and dead." 55 These thoughtful interpreters are Donne's audience as well as his interpretive authorities, and together they make up his vision of the English church as a community of believers, as well as a public, national, uniquely Reformed institution, still working out the terms of its doctrine, discipline, and devotion. Annabel Patterson has said that "meane waies" could be the title of "A Litanie." I would go further and say that "meane waies" and their "poetic" expression were the foundation of Donne's religion, and the spirit of his profession of faith.

\section{Notes}

1. This event and the discussion it precipitated are analyzed in full in the following articles: Dayton Haskin, “Is There a Future for Donne's 'Litany'?” John Donne Journal 21 (2002): 51-88, and Annabel Patterson, "A Man to Himself a Dioclesian: Donne's Rectified Litany,” John Donne Journal 21 (2002): 35-49.

2. The panel consisted of Richard Todd (who discussed textual cruxes), Dayton Haskin (who discussed the poem's interpretive history), and Annabel Patterson (who brought that interpretation into the twenty-first century). The poem comprises twenty-eight 
stanzas (252 lines). Its structure is complex, its style allusive and elliptical - not to mention paradoxical. One only wishes that Ramie Targoff had been there to test her hypothesis that the poem is unimaginable as a vehicle of worship, either public or private, and that it fails in creating a "devotional voice" (The Language of Public Devotion in Early Modern England [Chicago: University of Chicago Press, 2001], pp. 92-94).

3. Haskin, "Is There a Future for Donne's 'Litany'?”, p. 65.

4. Patterson, “A Man to Himself a Dioclesian,” p. 35.

5. Haskin, “Is There a Future for Donne's 'Litany'?”, p. 62.

6. Patterson, "A Man to Himself a Dioclesian," pp. 43, 48-49. Haskin ("Is There a Future for Donne's 'Litany'?") extends the reach of Donne's experiment in "A Litanie," asking whether this poem might articulate "longings for a more efficacious and global vision of human solidarity across time as well as space, and across religions as well as cultures" (p. 63).

7. Patterson, “A Man to Himself a Dioclesian,” pp. 48-49.

8. For a compelling account of Donne's shifting via media, see Joshua Scodel, "John Donne and the Religious Politics of the Mean," in John Donne's Religious Imagination: Essays in Honor of John T. Shawcross, ed. Raymond-Jean Frontain and Frances M. Malpezzi (Conway: University of Central Arkansas Press, 1995), pp. 45-80.

9. Beginning with his article on the Donne revival from Grosart to Eliot, Haskin has contributed a great deal to our ongoing reassessment of cultural engagements with Donne in the nineteenth and early twentieth centuries. See Dayton Haskin, "New Historical Contexts for Appraising the Donne Revival from A. B. Grosart to Charles Eliot Norton," ELH 56 (1989): 869-95.

10. See John Carey, John Donne: Life, Mind and Art (London: Faber, 1981), and R. C. Bald, John Donne: A Life (Oxford: Oxford University Press, 1970). As Dennis Flynn has shown, Bald saw his biography as merely "supplementary" to Walton's hagiographical account, offering "the sobering struggle for advancement" rather than the "hand of God blessing Donne with Protestantism" as the guiding principle of Donne's life (John Donne and the Ancient Catholic Nobility [Indianapolis: Indiana University Press, 1995], p. 10). Carey extends these assumptions into a narrative of "apostasy" and "ambition" but offers no new biographical evidence to support his claims. For an analysis of the history of biographical scholarship on Donne, see Flynn, pp. 1-16.

11. T. S. Eliot, "Lancelot Andrewes," in Selected Essays (London: Faber and Faber, 1932), p. 351. Peter McCullough's brilliant comparison of Donne and Andrewes, delivered as a plenary address to the John Donne Society Conference, 22 February 2003, is forthcoming in John Donne Journal 22 (2003).

12. This view, advanced forcefully by John Carey and Debora Shuger (Habits of Thought in the English Renaissance [Berkeley: University of California Press, 1990]), has been challenged by several commentators, especially Annabel Patterson, "John Donne, Kingsman?" in The Mental World of the Jacobean Court, ed. Linda Levy Peck (Cambridge: Cambridge University Press, 1991), pp. 251-72; David Norbrook, "The Monarchy of Wit and the Republic of Letters: Donne's Politics," in, Soliciting Interpretation: Literary Theory and Seventeenth-Century Poetry, ed. Elizabeth Harvey and Katherine E. Maus (Chicago: University of Chicago Press, 1990), pp. 3-36; and Scodel. My various interventions into the discussion of Donne's politics and religion are 
96 / Renaissance and Reformation / Renaissance et Réforme

subsumed in my book, John Donne and Conformity in Crisis in the Late Jacobean Pulpit (Cambridge: D. S. Brewer, 2003).

13. George Potter and Evelyn Simpson, eds., The Sermons of John Donne, 10 vols. (Berkeley: University of California Press, 1953-62). All quotations from Donne's sermons will be taken from this edition and cited by page and line number in the text of the essay.

14. William Mueller, John Donne, Preacher (Princeton, NJ: Princeton University Press, 1962), p. 149.

15. Ibid., pp. 193-94.

16. Ibid., p. 194.

17. Ibid., p. 256. Mueller distinguishes between the "relevant intensity" or "absorption in the text" that Eliot recognized in Andrewes and what he calls the "existential intensity" of Donne, which he describes as an "absorption in the relationship between Creator and created," a "passionate concern with the ways of man under God, along with the skill to express this relationship with a dramatic vividness" (p. 246).

18. The term has been salvaged by Patrick Collinson and Peter Lake, among others. See Patrick Collinson, The Puritan Character: Polemics and Polarities in Early Seventeenth-Century English Culture (Los Angeles: William Andrews Clark Memorial Library, 1989), and Peter Lake, "Defining Puritanism—again?", in Puritanism: Transatlantic Perspectives on Seventeenth-Century Anglo-American Faith, ed. Francis J. Bremer (Boston: Massachusetts Historical Society, 1993), pp. 3-29. Lake rehearses the recent historiography of the term "Puritanism" and attempts to "pull together a sense of the central core of a Puritan style or tradition or world view" (p. 6). Lake admits that he wants to complicate the "simple dichotomy between "Anglican mainstream' and 'Puritan opposition' while at the same time insisting on the existence of an identifiable Puritan tradition of thought and feeling, a style of subjectivity and way of looking at the world, running throughout the period" (p. 9). His modifications of Collinson and Peter White are founded on his observation that both positions "want to marginalize the notion of Puritanism, the one by collapsing it into the religion of protestants, the other by excluding it altogether from an 'Anglican' mainstream," and that both "rely heavily on the view of themselves taken by particular contemporary ideological factions" (p. 28). Lake's stress on the fact that we are dealing with "ideologically and polemically constructed views of order and disorder, orthodoxy and heresy, normality and deviance" (p. 29) shows how important it is to retain the word and concept of Puritanism, but also explains why other dichotomies (such as Calvinist/Arminian) fall into the same interpretive problems and ought to be resisted.

19. Nicholas Tyacke, Anti-Calvinists: The Rise of English Arminianism c. 1590-1640 (Oxford: Clarendon Press, 1987).

20. Anthony Milton, Catholic and Reformed: The Roman and Protestant Churches in English Protestant Thought, 1600-1640 (Cambridge: Cambridge University Press, 1995), p. 5; Milton's note on terminology (pp. 7-9) is essential reading for anyone entering the discussion of "religion" in this period. See also Kenneth Fincham and Peter Lake, “The Ecclesiastical Policy of King James I," Journal of British Studies 24 (1985): 169-207.

21. I am using the term "Calvinist" as defined by Anthony Milton: "The term 'Calvinist' is used, in common with current historiography, to denote a general sympathy with the continental Reformed tradition in all its purely doctrinal aspects, and a sense of 
identification with the West European Calvinist churches and their fortunes" (Catholic and Reformed, p. 8).

22. Lori Anne Ferrell and Peter McCullough, The English Sermon Revised: Religion, Literature, and History 1600-1750 (Manchester: Manchester University Press, 2000), p. 16.

23. Ferrell and McCullough, pp. 16, 12. Lake's case studies of Hall, Sanderson, and Skinner in particular are important contributions to this mode of analysis.

24. Biographical work by Paul Sellin on Donne's participation in the Doncaster embassy on the continent ("So Doth, So Is Religion": John Donne and Diplomatic Contexts in the Reformed Netherlands, 1619-20 [Columbia: University of Missouri Press, 1988]) and by Flynn on Donne's early years has supported strongly opposed readings of Donne's religion. Sellin's Donne is essentially Calvinist, while Flynn's is connected irrevocably to his Catholic past. These various attributions are handled in some detail in my book, John Donne and Conformity in Crisis.

25. There is seminal work by Peter Lake ("Anti-popery: the structure of a prejudice," in Conflict in Early-Stuart England: Studies in Politics and Religion, 1603-1642, ed. Richard Cust and Anne Hughes [London: Longman, 1989], pp. 72-106); Anthony Milton, Catholic and Reformed; Alexandra Walsham, Church Papists: Catholicism, Conformity and Confessional Polemic in Early Modern England (London: Boydell and Brewer, 1993); and Michael Questier, Conversion, Politics and Religion in England, 1580-1625 (Cambridge: Cambridge University Press, 1996).

26. As Lake and Questier observe, "Too often the subjects discussed in this volume are talked about by historians with reference only to intra-Protestant dispute. As the losers and therefore the ultimate outsiders, the supposedly monolithic 'other' against which the identity of the national church was habitually constructed and reconstructed, Catholics are very often left out of the account" (Introduction, Conformity and Orthodoxy in the English Church, c. 1560-1660, ed. Peter Lake and Michael Questier [Woodbridge: Boydell Press, 2000], p. 209).

27. Peter Lake, with Michael Questier, The Antichrist's Lewd Hat: Protestants, Papists and Players in Post-Reformation England (New Haven, CT: Yale University Press, 2002), p. 310.

28. Ibid., p. 321.

29. Alison Shell, Catholicism, Controversy and the English Literary Imagination, 15581660 (Cambridge: Cambridge University Press, 1999), p. 15.

30. Ibid.

31. Louise Guiney, "Donne as a Lost Catholic Poet," The Month 136 (1920): 13. Of "A Litanie," Guiney remarked that it is "fragrant with Catholic feeling, but not everywhere" (p. 15), but she concludes that "No label fixed upon him now will help readers to understand" the "burning truthfulness" of his "fundamentally religious" and "sincere” spirit (p. 18). Writing about Coleridge's marginalia on Donne's sermons, Dayton Haskin has elucidated some of the implications of Donne's early Catholicism that Coleridge admired, particularly his habits of annotation, including his engagement with the "learned opinions of Catholic interpreters of the Bible" ("Coleridge's Marginalia on the Seventeenth-Century Divines and the Perusal of our Elder Writers," John Donne Journal 19 [2000]: 326-27).

32. See my book, John Donne and Conformity in Crisis. 
98 / Renaissance and Reformation / Renaissance et Réforme

33. See especially Scodel.

34. The most important recent contributions to this subject are Theresa DiPasquale, Literature and Sacrament: The Sacred and the Secular in John Donne (Pittsburgh, PA: Duquesne University Press, 1999); Robert V. Young, Doctrine and Devotion in Seventeenth-Century Poetry (Cambridge: D. S. Brewer, 2000); Robert Whalen, The Poetry of Immanence: Sacrament in Donne and Herbert (Toronto: University of Toronto Press, 2002). See also Achsah Guibbory, Ceremony and Community from Herbert to Milton (Cambridge: Cambridge University Press, 1998), chap. 2.

35. Joan Webber, Contrary Music: The Prose Style of John Donne (Madison: University of Wisconsin Press, 1963). Although the sacramental nature of Donne's language is central to her argument and is sensitively drawn, Webber's work is noted only briefly by Whalen (p. 191, n. 45) and not at all by DiPasquale or Young (Doctrine and Devotion).

36. DiPasquale, p. 5.

37. Ibid., p. 9.

38. Ibid., p. 251.

39. Young, Doctrine and Devotion, p. 32. Young's essay "Donne and Bellarmine," John Donne Journal 19 (2000), 223-34, demonstrates beautifully that Donne frequently consulted and agreed with Bellarmine on the Psalms. Here Young concludes that Donne was "deliberately, if discreetly, distancing himself from Calvin's rigorous double predestination" (p. 232).

40. Young, Doctrine and Devotion, p. 99.

41. Whalen, p. xviii.

42. DiPasquale, pp. 259, 258.

43. Young, Doctrine and Devotion, pp. 96, 98, 99.

44. Whalen, p. 109. Whalen's discussion of the Christmas 1626 sermon is impressive for the way in which it combines its reading of the sermon with an attempt to historicize the moment in which these rhetorical formulations are offered.

45. Lake and Questier, Conformity and Orthodoxy, p. 321.

46. Questier, Conversion, p. 206.

47. The metaphors of "circumcision" and "concision" derive from an undated sermon on Philippians 3:2: "Beware of the concision" (10:103-18). The two undated sermons on the Reformation are numbers 6 and 7 of Volume 10 of the Potter and Simpson edition (pp. 140-77), both on Ezekiel 34:19: "And as for my Flock, they eate that, which yee have trodden with your feet, and they eat that which yee have fouled with your feet." It is likely that these sermons date from 1624 or 1625 . Donne's references to a current controversy on private communion can be connected to the official public response to Edward Elton's posthumously published book on the commandments in the first part of 1624/5. Donne contrasts the inflexibility of Calvin's self-proclaimed followers on the issue of private sacraments with Calvin's own willingness to depart from his own opinion in indifferent matters for the sake of confessional harmony, and to recognize the "indifferent" status of even such an important matter as the administration of the sacrament. Stuteville reports the suspension of Mr. Denison, a lecturer, for maintaining the lawfulness of private communion advanced in Elton's book, and the burning of these books at Paul's Cross early in 1624/5 (Thomas Birch, The Court and Times of 
James the First; Illustrated by Authentic and Confidential Letters, from Various Public and Private Collections, 2 vols. [London, 1849], 2: 491, 498).

48. On Donne's renovation of controverted terms, see my book, John Donne and Conformity in Crisis, pp. 26, 31-32, 77, 87, 95, 98, 152, 228, 235, 243-44, 254, 258, 260-61, 262, 274.

49. Anthony Milton, "A Qualified Intolerance: the Limits and Ambiguities of Early Stuart Anti-Catholicism," in Catholicism and Anti-Catholicism in Early Modern English Texts, ed. Arthur F. Marotti (Houndmills, Basingstoke, Hampshire: Macmillan, 1999), p. 110.

50. Donne's second sermon on Ezekiel 34:19 recounts the story of a serial convert, identified in the margin as "Peletier," who said that the best religion was "the religion I left, the reformed religion, . . . for when I changed, I had this religion, the Roman religion, for it, and three hundred Crowns a year to boot" (10: 161, 82-84).

51. I discuss these images as part of Donne's qualifications of rigid Calvinism in John Donne and Conformity in Crisis, pp. 89, 97-98, 282, 283.

52. Quoted in Haskin, "Coleridge's Marginalia," p. 322.

53. For an informative discussion of historical distance and its effects, see J.R. de J. Jackson, Historical Criticism and the Meaning of Texts (New York: Routledge, 1989).

54. The elegies that accompanied Donne's poems in 1633 and 1635 are shot through with the language of Donne's originality. While some of this is conventional in elegies, the emphasis on Donne's unique "wit," both in his poems and in the pulpit, is unmistakable.

55. Haskin, “Coleridge's Marginalia,” pp. 330-31. 